\title{
Increased Expression of c-jun, junB, AP-1, and Preproenkephalin mRNA in Rat Striatum Following a Single Injection of Caffeine
}

\author{
Per Svenningsson, ${ }^{1}$ Anders Ström, ${ }^{2}$ Björn Johansson, ${ }^{1}$ and Bertil B. Fredholm ${ }^{1}$ \\ 'Department of Physiology and Pharmacology, Center for Pharmacology, Karolinska Institutet, S-171 77 Stockholm, \\ Sweden and ${ }^{2}$ Department of Medical Nutrition, Huddinge Hospital, S-141 86 Huddinge, Sweden
}

The effect of a single injection of caffeine on the expression of c-fos, c-jun, junB, and junD, on activator protein 1 (AP-1) and on the levels of preproenkephalin mRNA in rat striatum was studied. Male rats were given caffeine (25 $\mathrm{mg} / \mathrm{kg}, 50 \mathrm{mg} / \mathrm{kg}$, or $100 \mathrm{mg} / \mathrm{kg}$, i.p.) and sacrificed at different times $(0.5,1,2,4$, or $8 \mathrm{hr})$ after administration. By using in situ hybridization of adjacent sections we found a rapid, transient, and dose-dependent increase of c-fos, cjun, and junB by caffeine in striatum, especially in the lateral part. The induction peaked after $1 \mathrm{hr}$, but persisted for $2 \mathrm{hr}$, and in the case of junB for $4 \mathrm{hr}$. No induction of junD was found. A strong induction of junB, a weak induction of c-fos and c-jun, but not of junD, was seen in nucleus accumbens. Furthermore, by using gel shift assay we found an induction of AP-1 by caffeine $(100 \mathrm{mg} / \mathrm{kg})$ in striatum, which peaked $2 \mathrm{hr}$ after administration and was clearly increased after $4 \mathrm{hr}$. c-Fos, c-Jun, and JunB proteins were components of the AP-1. There was also a dose-dependent induction of preproenkephalin mRNA, which was most pronounced in the lateral and caudal part of striatum; the level peaked $4 \mathrm{hr}$ after injection and was still significantly increased after $8 \mathrm{hr}$. In a complementary study we could not find increased binding to the AP-1-like site in the $5^{\prime}$-flanking sequence of proenkephalin following caffeine treatment.

The data show that a single dose of caffeine induces a temporally and spatially characteristic pattern of c-fos, c-jun, and junB induction, followed by changes in AP-1 and preproenkephalin mRNA. Thus, a single dose of caffeine causes changes in gene transcription in the brain that may be related to the adaptive changes that occur after caffeine administration. However, a direct causal link between the immediate early genes and enkephalin could not be proven.

[Key words: caffelne, Immedlate early genes, AP-1, enkephalin, gel shift assay, in situ hybridization]

Caffeine is the most widely consumed psychomotor stimulant (Nehlig et al., 1992). The mechanism(s) underlying the central actions of caffeine are probably complex (for reviews, see Neh-

\footnotetext{
Recived May 11, 1994; revised Nov. 28, 1994; accepted Dec. 1, 1994

These studies were supported by the Swedish Medical Research Council (Project 2553), by the Swedish Cancer Fund, by the Institute for Scientific Information on Coffee, and by Karolinska lnstitutet. B.J. was a recipient of a Swedish Medical Research Council graduate fellowship.

Correspondence should be addressed to Per Svenningsson, Department of Physiology and Pharmacology, Karolinska Institutet, S-171 77 Stockholm, Sweden

Copyright (C) 1995 Society for Neuroscience $0270-6474 / 95 / 153583-11 \$ 05.00 / 0$
}

lig et al., 1992; Daly, 1993). An important role is apparently played by adenosine receptors which are inhibited by caffeine in concentrations similar to those encountered in humans after normal caffeine use (Fredholm, 1980). Only at higher concentrations does caffeine inhibit cAMP phosphodiesterases or release intracellular calcium. Of the four adenosine receptors that have been cloned, the adenosine $A_{1}$ and $A_{2 i}$ receptors are the most likely sites of action of caffeine (see Fredholm et al., 1994). Adenosine $A_{2 \mathrm{a}}$ receptors are enriched in striatum (Parkinson and Fredholm, 1990) whereas adenosine $A_{1}$ receptors have a wide distribution in the CNS and are present in striatum (Fastbom et al., 1987).

In order to examine the neuronal basis of caffeine action we have used the approach pioneered by Sagar and coworkers (1988), namely to map the induction of immediate early genes following drug treatment. Caffeine induces c-fos in the lateral part of striatum, in both substance $P$ - and enkephalin-containing GABAergic medium-sized spiny neurons (Johansson et al., 1994). This is in contrast to c-fos induction by cocaine and amphetamine which is restricted to substance $\mathrm{P}$-containing neurons (Young et al., 1991; Beretta et al., 1992).

c-fos is a member of a family of immediate early genes that also includes, for example, c-jun and junB. Recently it was reported that jun $\mathrm{B}$ was induced parallel with $\mathrm{c}-$ fos following cocaine administration, whereas c-jun was not altered (Moratalla et al., 1993). A different pattern of expression was found in the spinal cord after peripheral stimulation and in brain after seizures (Dragunow and Robertson, 1987; Morgan et al., 1987; Saffen et al., 1988; Sonnenberg et al., 1989b; Wisden et al., 1990; Herdegen et al., 1991a,b; Uhl et al., 1991). These findings suggest the possibility that depending on the stimulus there is a characteristic pattern of expression of immcdiatc carly gencs.

The different members of the Fos/Jun family of immediate early genes combine to form homodimers and heterodimers that bind to the activator protein 1 (AP-1) consensus sequence (Nakabeppu et al., 1988). The basal expression of AP-1 in rat striatum in vivo is weak, but is inducible, for example, following amphetamine administration (Nguyen et al., 1992; Wang et al., 1992).

AP-1 may be involved in the regulation of the neuropeptide enkephalin in vitro (Comb ct al., 1988; Sonnenberg et al., 1989a). However, it has recently been reported that AP-1 is not important for this regulation in vivo (Konradi et al., 1993). Enkephalin and preproenkephalin mRNA are found almost exclusively in GABAergic medium-sized spiny neurons projecting to the globus pallidus (Gerfen and Young, 1988). The level of preproenkephalin mRNA increases, in the lesioned side, in rats with 
unilateral 6-hydroxydopamine lesions of the nigrostriatal dopamine pathway (Young et al., 1986; Gerfen et al., 1990, 1991) following acute or chronic treatment with dopamine $D_{2}$ receptor antagonists (Tang et al., 1983; deCeballos et al., 1986; Taylor et al., 1991; Angulo, 1992). Recently it has also been reported that chronic treatment with caffeine causes increased levels of preproenkephalin mRNA (Schiffmann and Vanderhaeghen, 1993a).

Here we report that a single injection of caffeine causes not only the previously demonstrated induction of $\mathrm{c}-f o s$, but also an induction of $\mathrm{c}-j u n$ and $j u n \mathrm{~B}$, and also that the levels of the transcription factor AP-1 and preproenkephalin mRNA are increased. We also present data indicating that the AP-1-like site in the proenkephalin enhancer does not bind AP-1.

\section{Materials and Methods}

Animals and drug treatment. Male Sprague-Dawley rats (ALAB, Stockholm. Sweden) weighing $200-220 \mathrm{gm}$ were injected intraperitoneally (i.p.) with saline or with caffeine (Sigma, Labkemi, Stockholm, Sweden) $25 \mathrm{mg} / \mathrm{kg}, 50 \mathrm{mg} / \mathrm{kg}$, or $100 \mathrm{mg} / \mathrm{kg}$. Thirty minutes, $1 \mathrm{hr}, 2 \mathrm{hr}, 4$ hr, or $8 \mathrm{hr}$ after injection rats were briefly anesthetized with $\mathrm{CO}_{2}$ and killed immediately by decapitation. There is no difference in caffeineinduced c-fos in rats briefly anesthetized with $\mathrm{CO}_{2}$ before sacrifice and rats sacrificed without being $\mathrm{CO}_{2}$-anesthetized (P. Svenningsson, B. Johansson, and B. B. Fredholm, unpublished observations). The brain was rapidly dissected out, frozen on dry ice, and stored at $-20^{\circ} \mathrm{C}$ for less than a week until sectioning (see below).

In situ hybridization. Coronal sections $(14 \mu \mathrm{m})$ were made through striatum, thalamus, hippocampus, and cerebellum and thaw-mounted on poly-L-lysine $(50 \mathrm{mg} / \mathrm{ml})$-coated slides. For cellular colocalization studies consecutive $5 \mu \mathrm{m}$ sections were made.

Sections were thereafter hybridized in a cocktail containing $50 \%$ deionized formamide (Fluka, Buchs, Switzerland), $4 \times \operatorname{SSC}(3 \mathrm{M} \mathrm{NaCl}$, $0.3 \mathrm{M}$ trisodium citrate), $1 \times$ Denhardt's solution, $1 \%$ sarcosyl, $0.02 \mathrm{M}$ $\mathrm{NaPO}_{+}(\mathrm{pH} 7.0), 10 \%$ dextran sulfate, $0.5 \mathrm{mg} / \mathrm{ml}$ yeast tRNA (Sigma, Labkemi, Stockholm, Sweden), $0.06 \mathrm{M}$ dithiothreitol, $0.1 \mathrm{mg} / \mathrm{ml}$ sheared salmon sperm DNA, and $10^{7} \mathrm{cpm} / \mathrm{ml}$ of probe. After hybridization for $15 \mathrm{hr}$ at $42^{\circ} \mathrm{C}$, the sections were washed four times, for $15 \mathrm{~min}$ each, in $1 \times \mathrm{SSC}$ at $55^{\circ} \mathrm{C}$, dipped briefly in water, $70 \%, 95 \%$, and $99.5 \%$ ethanol and air dried: $14 \mu \mathrm{m}$ sections were apposed to Hyperfilm- $\beta_{\text {max }}$ (Amersham, Solna, Sweden) for $2-4$ weeks. For the colocalization studies consecutive $5 \mu \mathrm{m}$ sections were incubated with different probes and dipped in NTB-3 emulsion (Kodak, Järfälla, Sweden) and exposed for 4-7 weeks. After the emulsion had been developed, sections were lightly counterstained in cresyl violet $(0.5 \%)$.

Films were analyzed with a Microcomputer Imaging Device (Imaging Research). Results are presented as relative optical density, and film background was subtracted from all measured values. Emulsion autoradiograms were evaluated by inspection in a light microscope or by analyzing photographs. Cells that showed a grain density at least four times the background were considered to be labeled, the remaining cells unlabeled. To identify neuron-like cells in two consecutive sections, landmark structures (blood vessels, etc.) were identified in both sections and the two sections virtually superimposed using the image analysis system.

Oligonucleotide probes. The following oligonucleotide probes were used in this study: c-fos, 48 bases long, complementary to rat c-fos mRNA encoding amino acids 137-152 of the c-Fos protein (Curran et al., 1987); c-jun, 45 and 48 bases long, complementary to mouse c-jun mRNA encoding amino acids $123-137$ and 265-280 of the c-Jun protein (Lamph et al., 1988); jun B, 48 bases long, complementary to mouse jun B mRNA encoding amino acids 195-210 of the JunB protein (Ryder et al., 1988); junD, 48 bases long, complementary to junD mRNA encoding amino acids 200-215 of the JunD protein (Hirai et al., 1989); preproenkephalin, 48 bases long, complementary to nucleotides $388-$ 435 of rat preproenkephalin gene (Yoshikawa et al., 1984); preprotachykinin, 48 bases long, complementary to nucleotides 124-171 of the rat preprotachkinin A gene (Krause et al., 1987). All probes were synthesized by Scandinavian Gene Synthesis AB, Köping, Sweden. The specificity of each probe has been tested earlier (Moratalla et al., 1993; Johansson et al., 1994; $\AA$. Dagerlind, personal communication).

Oligodeoxyribonucleotides were radiolabeled using terminal deoxynucleotidyl transferase (Pharmacia LKB, Uppsala, Sweden) and $\alpha-{ }^{35} S$ -
dATP (Du Pont New England Nuclear, Stockholm, Sweden) to a specific activity of about $10^{\circ} \mathrm{cpm} / \mathrm{gm}$.

Gel shift assay. Striatum was immediately dissected from the brain and frozen at $-80^{\circ} \mathrm{C}$. Each striatum was then manually ground in an Eppendorf tube. Thereafter the cells were lysed with $50 \mathrm{ml}$ of buffer [10 mM HEPES-KOH (pH 7.9), $0.4 \mathrm{M} \mathrm{NaCl}, 0.1 \mathrm{~mm}$ EDTA, 5\% glycerol, I $\mathrm{mm}$ dithiothreitol, $2 \mathrm{~mm}$ phenylmethane sulfonylfluoride]. The samples were centrifuged at $10,000 \times \mathrm{g}$ for $15 \mathrm{~min}$, the supernatants were collected, aliquoted in small volumes, and frozen at $-135^{\circ} \mathrm{C}$ until used. The protein content was measured as described by Bradford (1976) and diluted to the same concentration. We used whole-cell extracts in this experiment for two reasons. First, the association of Fos and Jun proteins occurs in the nucleus (Curran et al., 1990), so all of the measured AP-1 is probably located to nucleus and can act as transcription factor. Second, the preparation of proteins from whole-cell extracts is rapid and the activity of proteases and phosphatases is limited.

The AP-1 binding sites were double-stranded synthetic oligonucleotides, CCATGGTTGCTGACTAATTGAGATCT, deduced from the SV 40 enhancer (Jones et al., 1988) and, AAGCATGAGTCAGACAC, from the collagenase enhancer (Lee et al., 1987). The ENKCRE-2 binding site was a double-stranded synthetic oligonucleotide, GATCGGCCTGCGTCAGCTG, deduced from the proenkephalin enhancer (Comb et al., 1988; Konradi et al., 1993). The NF-1 binding site was a double-stranded synthetic oligonucleotide, ATTTTGGCTTGAAGCCAATATG, deduced from the adenovirus origin of replication (Chodosh et al., 1988). The oligos were end-labeled by using polynucleotide kinase and $\gamma^{-32}$-P-ATP (Amersham, Solna, Sweden).

Twenty micrograms of protein extract was incubated on ice water in $30 \mathrm{~mm}$ HEPES (pH 7.9), 6\% Ficoll (400), $80 \mathrm{~mm} \mathrm{KCl,} \mathrm{0.015 \%} \mathrm{NP} \mathrm{40,}$ $20 \mathrm{~mm} \mathrm{NaCl}, 0.1 \mathrm{mg} / \mathrm{ml}$ poly-dIdC for $10 \mathrm{~min}$. Thereafter $0.1 \mathrm{ng}$ of labeled probe was added to a final volume of $20 \mathrm{ml}$. For competition experiments a 100 -fold excess of unlabeled probe was added to the binding reaction. The samples were incubated for $1 \mathrm{hr}$ on ice-water. The resulting protein-DNA complexes were resolved on a preelectrophoresed $5 \%$ nondenaturating polyacrylamide gel in a buffer containing $25 \mathrm{~mm}$ Tris-borate, $0.5 \mathrm{~mm}$ EDTA, $0.02 \% \mathrm{NP} 40$. The gel was dried and autoradiographed on XAR film (Kodak, Järfälla, Sweden) for $1 \mathrm{~d}$.

Antibodies used in gel shift analysis. Specific antibodies to c-Fos, c-Jun, JunB, and JunD (Thierry et al., 1992, or those from Santa Cruz Biotechnology Inc., Santa Cruz, CA) were used. The antibodies were added $15 \mathrm{~min}$ after addition of the probe to the binding reaction.

Statistics. The differences between means \pm SEM were analyzed by single-factor analysis of variance (ANOVA) followed by pairwise group comparisons by the Tukey-Kramer method (SYSTAT).

\section{Results}

Effect of a single injection of caffeine on the expression of $c$-jun, jun $B, c$-fos, and jun $D$ in striatum

In situ hybridization against the four different oncogenes was done in adjacent sections from each animal. There was a clearcut induction of c-jun following administration of caffeine ( 100 $\mathrm{mg} / \mathrm{kg}$ ), which was most pronounced in the lateral part of caudate-putamen (Figs. 1, 2, 3a). The expression of c-jun was detected by two different probes, one identical with the probe used by Moratalla and coworkers (1993). The two probes showed identical results. No induction was found in rats treated with the lower doses of caffeine $(50 \mathrm{mg} / \mathrm{kg}$ and $25 \mathrm{mg} / \mathrm{kg})$. The c-jun level was highest at one hour after treatment and gradually returned towards control, which was reached at $8 \mathrm{hr}$ after caffeine administration. No induction of c-jun was observed in nucleus accumbens following administration of caffeine $(100 \mathrm{mg} / \mathrm{kg})$ (Figs. 1, 4a).

The expression of $j u n \mathrm{~B}$ following caffeinc administration was more marked and long-lasting than that of c-fos and c-jun. Thus, there was a rapid and prominent induction both throughout the caudate-putamen and in the nucleus accumbens following treatment with caffeine $(100 \mathrm{mg} / \mathrm{kg}$ ) (Figs. 1, 2, 3b, 4b). In both areas the highest levels of induction were observed $1 \mathrm{hr}$ after administration. The $j u n \mathrm{~B}$ in caudate-putamen was significantly 


\section{c-jun}
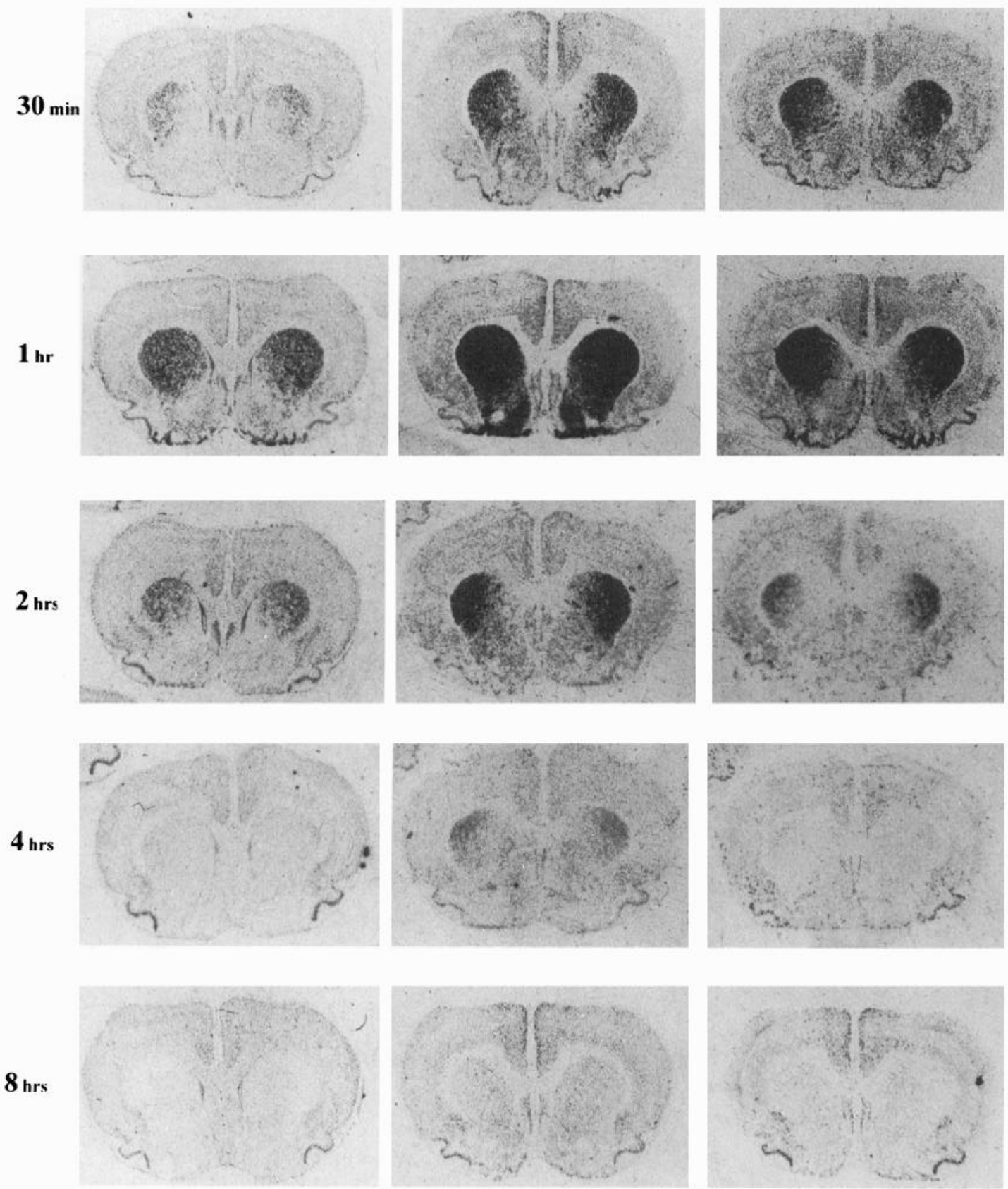

Figure 1. In situ hybridization autoradiograms showing the distribution of c-jun, jun B, and c-fos expression in coronal sections through the rostral part of striatum of rats treated with caffeine $(100 \mathrm{mg} / \mathrm{kg})$ and sacrificed after $30 \mathrm{~min}, 1 \mathrm{hr}, 2 \mathrm{hr}, 4 \mathrm{hr}$, or $8 \mathrm{hr}$.

elevated at $4 \mathrm{hr}$ after caffeine administration, but the induction in the nucleus accumbens was less persistent. There was a tendency to induction of jun $\mathrm{B}$ in rats treated with $50 \mathrm{mg}$ of caffeine per kilogram and sacrificed 1 or $2 \mathrm{hr}$ after administration, but no induction was seen in rats treated with the lowest dose of caffeine $(25 \mathrm{mg} / \mathrm{kg})$.

In agreement with previous studies (Nakajima et al., 1989; Johansson et al., 1994) there was a rapid and prominent induction of c-fos in striatum following administration of caffeine $(100 \mathrm{mg} / \mathrm{kg})$, which was most pronounced in the lateral part of caudate-putamen (Figs. 1, 2, 3c). The c-fos signal was strongest at $1 \mathrm{hr}$ after treatment and remained elevated for $2 \mathrm{hr}$. There was a tendency to a weak induction in rats treated with $50 \mathrm{mg}$ of caffeine per kilogram and sacrificed $1 \mathrm{hr}$ after administration, whereas the c-fos signal in rats treated with the lowest dose of caffeine $(25 \mathrm{mg} / \mathrm{kg})$ was indistinguishable from control. There was only a weak and statistically insignificant induction of c-fos in nucleus accumbens $1 \mathrm{hr}$ after administration of caffeine (100 $\mathrm{mg} / \mathrm{kg}$ ) (Figs. 1, 4c).

At the cellular level in the lateral part of rostral caudate-putamen, more neuron-like cells were labeled against jun $\mathrm{B}$ and c-fos than against c-jun (Fig. 5). No obviously glial-like cells 


\section{c-jun}

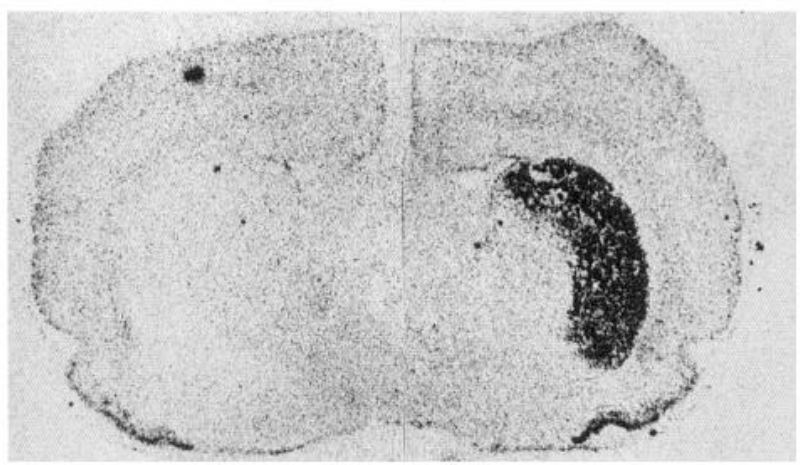

jun $\mathrm{B}$

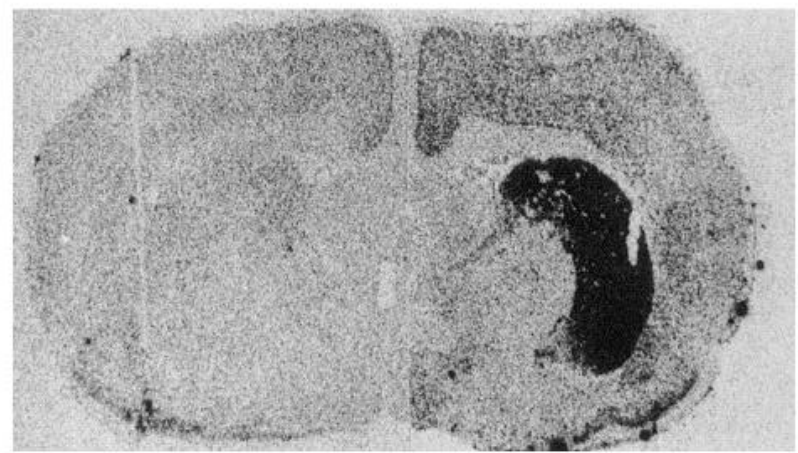

c-fos

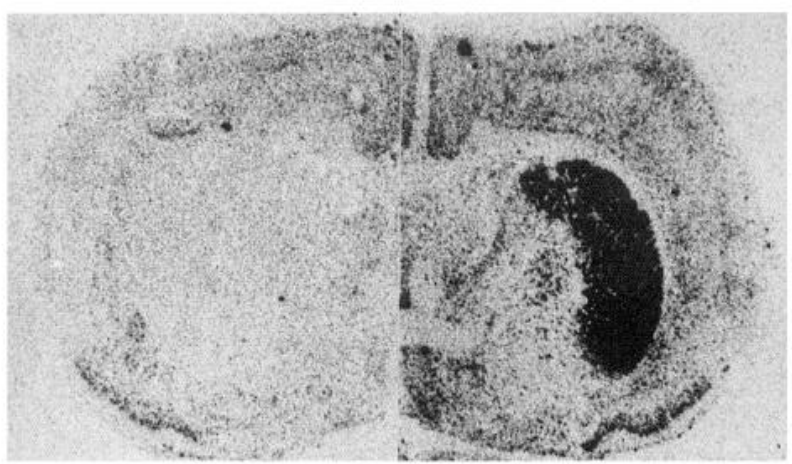

Figure 2. In situ hybridization autoradiograms showing the distribution of c-jun, jun $\mathrm{B}$, and c-fos expression in coronal sections through the caudal part of striatum of rats treated with saline (left hemisphere) or caffeine $(100 \mathrm{mg} / \mathrm{kg}$ ) (right hemisphere) and sacrificed $1 \mathrm{hr}$ after administration.

were labeled with any of the probes. Only some $25 \%$ of the cells in the study illustrated in Figure $5 c$ showed labeling with c-jun. The degree of labeling was somewhat higher $(40 \%)$ in a separate experiment. By contrast, the jun B and c-fos probes were detected in a much larger percentage of cells $80 \%(84 \%)$ and $67 \%(77 \%)$, respectively. The difference in the degree of labeling could not be attributed to a difference in the population of cells labeled. Instead all three probes labeled both preproenkephalin (ENK)
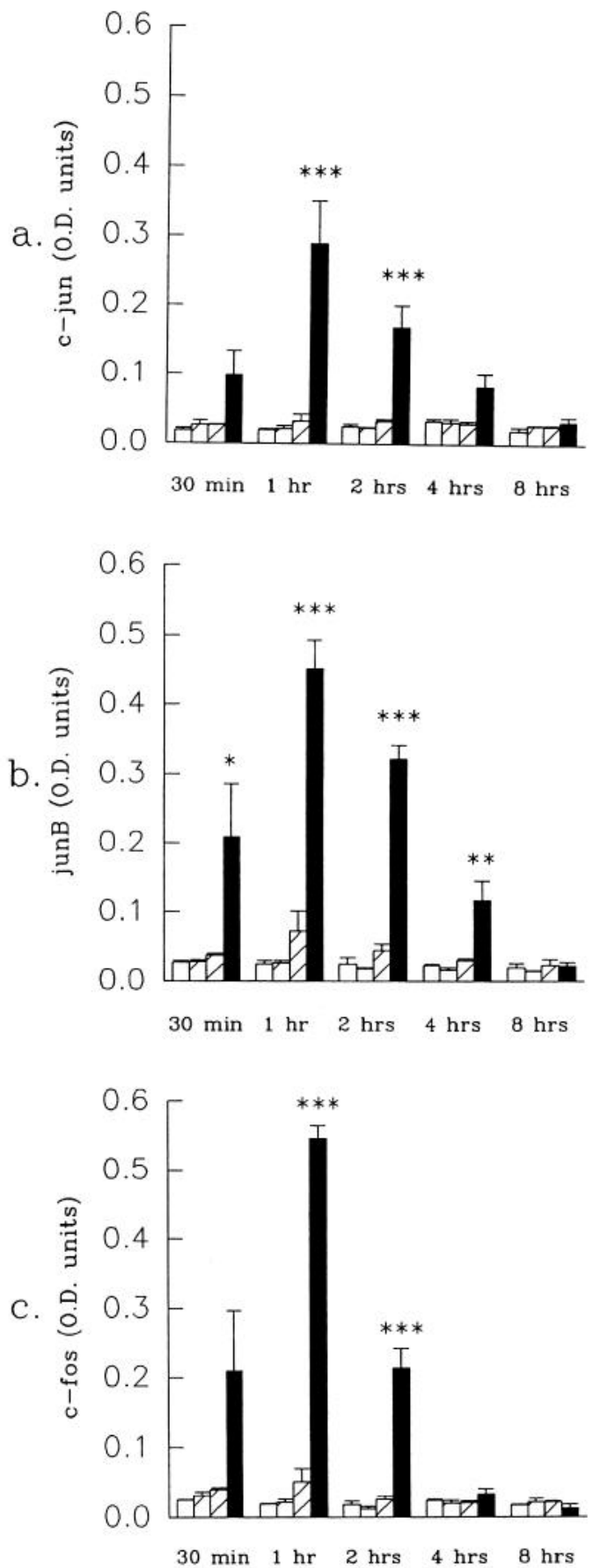

Figure 3. Histograms showing the time-course of c-jun (a.), jun B (b.), and $\mathrm{c}$-fos $(c$.) expression in the lateral part of rostral caudate-putamen following treatment with saline $(\square)$, caffeine $25 \mathrm{mg} / \mathrm{kg}(\square)$, caffeine $50 \mathrm{mg} / \mathrm{kg}(\square)$, or caffeine $100 \mathrm{mg} / \mathrm{kg}(\square)$. The results are given as the mean \pm SEM, from three individuals in each group. *, $P<0.05$; **, $P<0.01$; ***, $P<0.001$; each versus corresponding saline treated.

and preprotachykinin A (SP) expressing cells. Thus, c-jun was found in $27 \%$ of the ENK positive cells, $22 \%$ of the ENK negative cells, $27 \%$ of the SP positive cells, and $21 \%$ of the SP negative cells. For jun $\mathrm{B}$ the corresponding figures were 80,70 , 84 , and $86 \%$, and for c-fos they were $79,65,68$, and $64 \%(20$ 88 cells were counted in each category-the largest numbers in case of c-jun).

None of the treatments in this experiment caused induction of 
junD. The probe did, however, reveal a clear expression of junD in hippocampus (not shown) and cerebellum (Fig. 6), but this was not different from that seen in saline-treated animals.

Effect of a single injection of caffeine on expression of $c$-jun in ventral part of thalamus, jun $B$ in cerebral cortex, and $c$-fos in globus pallidus

An increased level of $c-j u n$ in the ventral part of thalamus, especially in ventral posteromedial and ventral posterolateral thalamic nucleus, was observed following treatment with caffeine (100 mg/kg) (Fig. 7), but no similar induction was found for the other oncogenes examined. An increased level of jun B and c-fos, but not of $c-j u n$, in the cerebral cortex was seen following administration of caffeine $(100 \mathrm{mg} / \mathrm{kg})$ (Fig. 2). The junB and c-fos increase was more clearcut in posterior parts of the cortex (not shown). Interestingly, c-fos tended to increase in globus pallidus following treatment with caffeine $(100 \mathrm{mg} / \mathrm{kg}$ ) (Fig. 2), but $\mathrm{no}$ increase in the other immediate early gene products was observed in this structure.

\section{Effect of a single injection of caffeine on expression of AP-1} in striatum

Caffeine $(100 \mathrm{mg} / \mathrm{kg}$ ) administration caused an induction of AP1 , which was clearly detectable already after $1 \mathrm{hr}$, peaked after $2 \mathrm{hr}$, and was well maintained $4 \mathrm{hr}$ after administration (Figs. $8 a, 9)$. By contrast, caffeine did not affect binding to CRE-2 at any of these time-points (Fig. $8 d$, results from rats treated $4 \mathrm{hr}$ not shown). The experiment was repeated five times with new cxtracts from different rats each time and the results were identical. Furthermore, identical results were obtained with two different probes against the AP-1 binding site. The results were not due to unspecific DNA-binding, since an excess of cold NF-1 (Fig. 8c) or CRE-2 (not shown) did not alter the AP-1 binding following caffeine treatment. Using super-shift assay it was demonstrated that at least some of the AP-1 complexes after $2 \mathrm{hr}$ contained JunB, c-Jun and c-Fos (Fig. $8 b$ ). The presence of JunD in AP-1 was also suggested. The same results were found in striatal extracts from four different rats injected with caffeine (100 $\mathrm{mg} / \mathrm{kg}$ ) and sacrificed $2 \mathrm{hr}$ after administration. The AP-1 complex obtained from animals $4 \mathrm{hr}$ after caffeine was shifted by antibodies against Jun B and c-Fos (Fig. $8 b$ ).

\section{Effect of a single injection of caffeine on preproenkephalin $m R N A$}

In agreement with previous results (Schiffmann et al., 1991) preproenkephalin mRNA was expressed throughout the caudate putamen and the nucleus accumbens (Fig. 10d). There was a clear-cut increase of preproenkephalin mRNA in the lateral part of caudate-putamen following administration of caffeine (100 $\mathrm{mg} / \mathrm{kg}$ ) (Figs. 10, 11, 12a). A small induction was seen already after $1 \mathrm{hr}$, but it peaked after $4 \mathrm{hr}$, and remained significantly increased even after $8 \mathrm{hr}$. The expression of preproenkephalin mRNA in rats treated with a lower dose of caffeine $(50 \mathrm{mg} / \mathrm{kg})$ and sacrificed after $4 \mathrm{hr}$ also tended to be higher than that of control animals. Irrespective of dose and duration of treatment, no induction was seen in nucleus accumbens following caffeine administration (Figs. 10, 12b).

\section{Discussion}

Effects of caffeine on immediate early genes in caudateputamen

The present study shows that a single injection of caffeine (100 $\mathrm{mg} / \mathrm{kg}$ ) is able to increase the expression of the immediate early
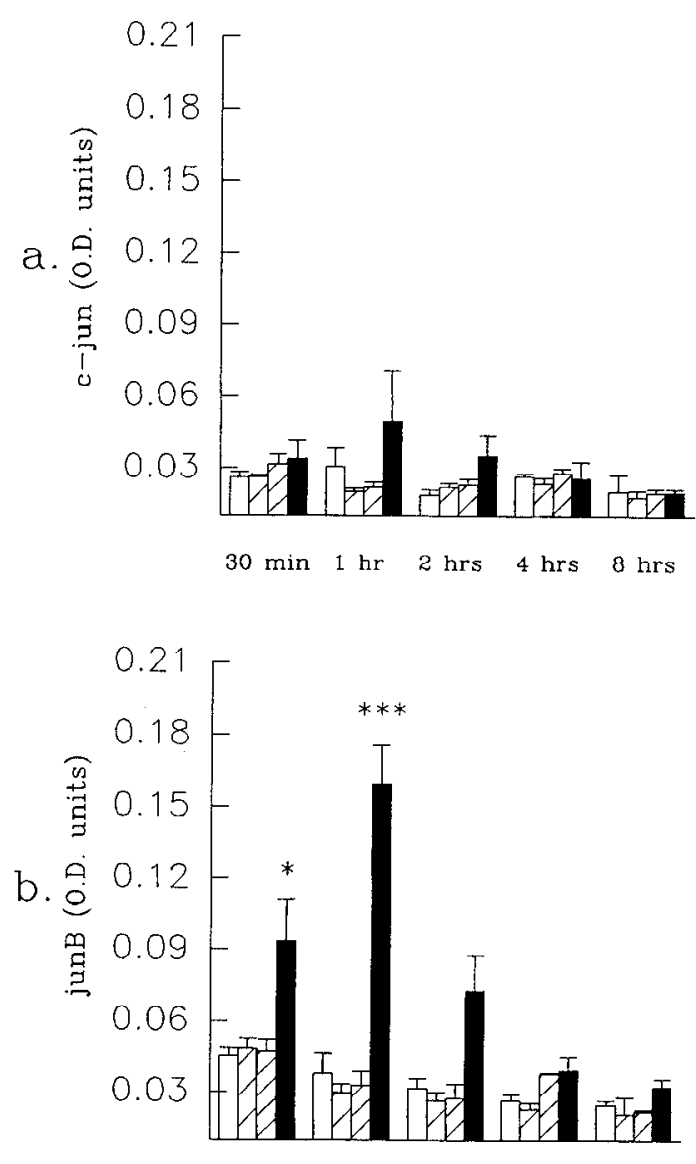

$30 \mathrm{~min} 1 \mathrm{hr} 2 \mathrm{hrs} 4 \mathrm{hrs} 8 \mathrm{hrs}$

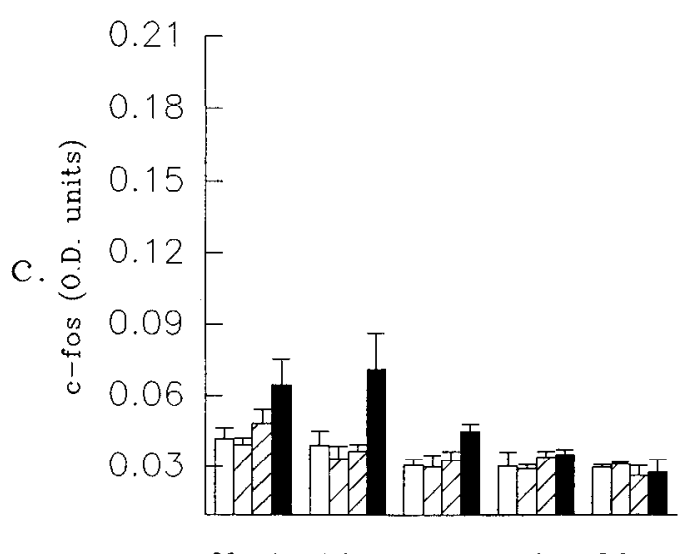

$30 \mathrm{~min} 1 \mathrm{hr} 2 \mathrm{hrs} 4 \mathrm{hrs} 8 \mathrm{hrs}$

Figure 4. Histograms showing the time-course of c-jun (a.), jun B (b.), and c-fos $(c$.) expression in nucleus accumbens following treatment with saline $(\square)$, caffeine $25 \mathrm{mg} / \mathrm{kg}(\square)$, caffeine $50 \mathrm{mg} / \mathrm{kg}$ (图), or caffeine $100 \mathrm{mg} / \mathrm{kg}(\square)$. The results are given as the mean $\pm \mathrm{SEM}$, from three individuals in each group. ${ }^{*}, P<0.05$; ${ }^{* * *}, P<0.001$; each versus corresponding saline treated.

genes $c-j u n$ and $j u n \mathrm{~B}$, but not $j u n \mathrm{D}$, and of the transcription factor AP-1 and preproenkephalin mRNA in striatum. We also confirm previous studies (Nakajima et al., 1989; Johansson et al., 1994) that show an induction of c-fos in striatum following caffeine administration. It is known that the basal levels of the fos and jun oncogenes differ between areas of the brain (Mellström et al., 1991). After drug treatment the fos and jun onco- 

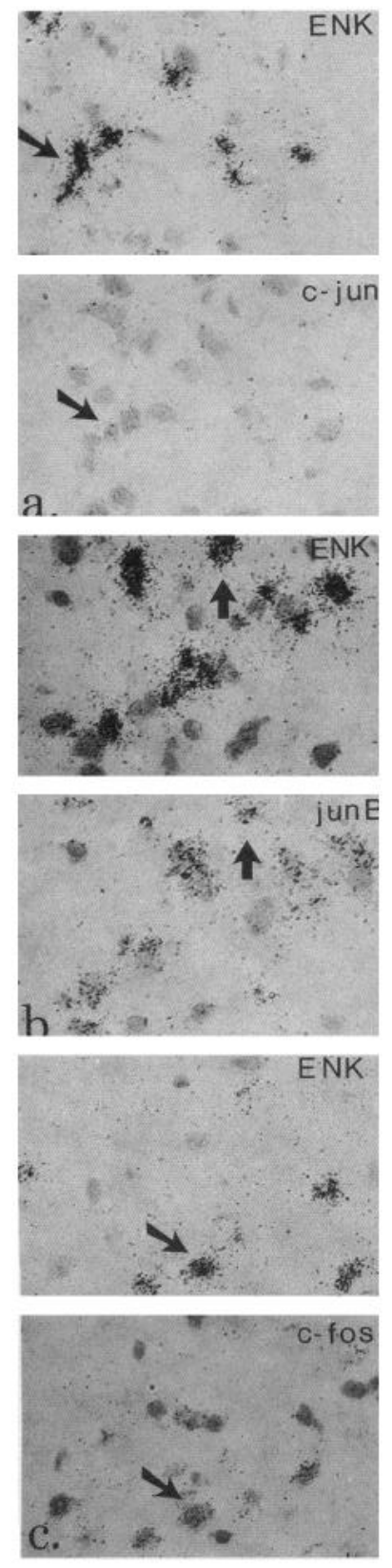

Figure 5. Emulsion autoradiograms from the lateral part of rostral caudate-putamen of a caffeine-treated rat $(100 \mathrm{mg} / \mathrm{kg})$, sacrificed $1 \mathrm{hr}$ after treatment, showing neuron-like cells labeled in thin, consecutive sections against preproenkephalin mRNA (ENK, top left) or preprotachykinin A mRNA ( $S P$, top right) and, for comparison, with probes for c-jun (panel a, bottom two parts), jun B (panel b, bottom two parts) and c-fos (panel c, bottom two parts). Arrows indicate cells that coexpress mRNA for the respective peptides and immediate early genes. Of the neuron-like cells examined $52 \%$ were positive for ENK, $53 \%$ for SP, $25 \%$ for c-jun, $80 \%$ for junB, and $67 \%$ c-fos. Between 119 and 282 cells were counted to obtain each percentage value.

genes are preferentially induced in some areas; this could provide an indicator of the neural systems that are activated.

In agreement with previous findings (Nakajima et al., 1989; Johansson et al., 1994) the induction of c-fos was seen only after rather high doses of caffeine. These doses of caffeine are much (more than 10-fold) higher than those that cause initial activation of motor behavior (see Daly, 1993). In fact, the doses required to induce a clearcut induction of the immediate early genes if
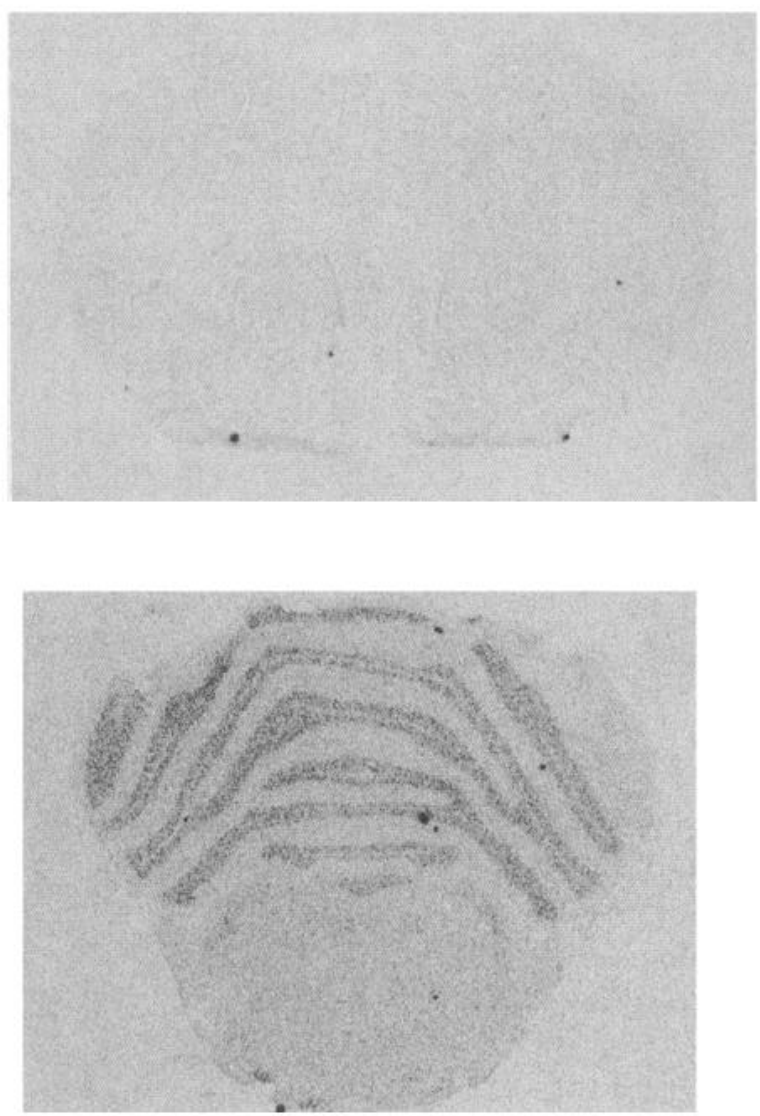

Figure 6. In situ hybridization autoradiograms showing the expression of jun D in coronal sections from the rostral part of striatum (upper panel) and cerebellum (lower panel) of a caffeine-treated rat (100 $\mathrm{mg} / \mathrm{kg}$ ), sacrificed $1 \mathrm{hr}$ after treatment.

anything cause a motor depression. This could mean that our results are not immediately relevant for an understanding of the neuronal basis of the excitatory actions of caffeine. Also other drugs, for example, cocaine and amphetamine, are behaviorally active in much lower doses than those required to stimulate immediate early gene expression (e.g., Moratalla et al., 1992, 1993).

Whereas information about changes in gene expression after caffeine treatment is limited, the ability of addictive compounds such as cocaine, amphetamine, and opiates to alter gene expression has been extensively studied (see Nestler et al., 1993). Since caffeine shares at least some behavioral characteristics with am-

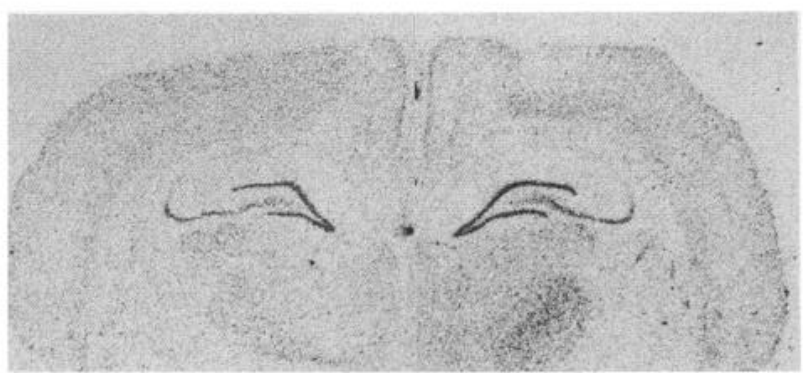

Figure 7. In situ hybridization autoradiograms showing the expression of c-jun in the ventral part of thalamus of rats treated with saline (left hemisphere) or caffeine $(100 \mathrm{mg} / \mathrm{kg}$ ) (right hemisphere) and sacrificed after $1 \mathrm{hr}$. 

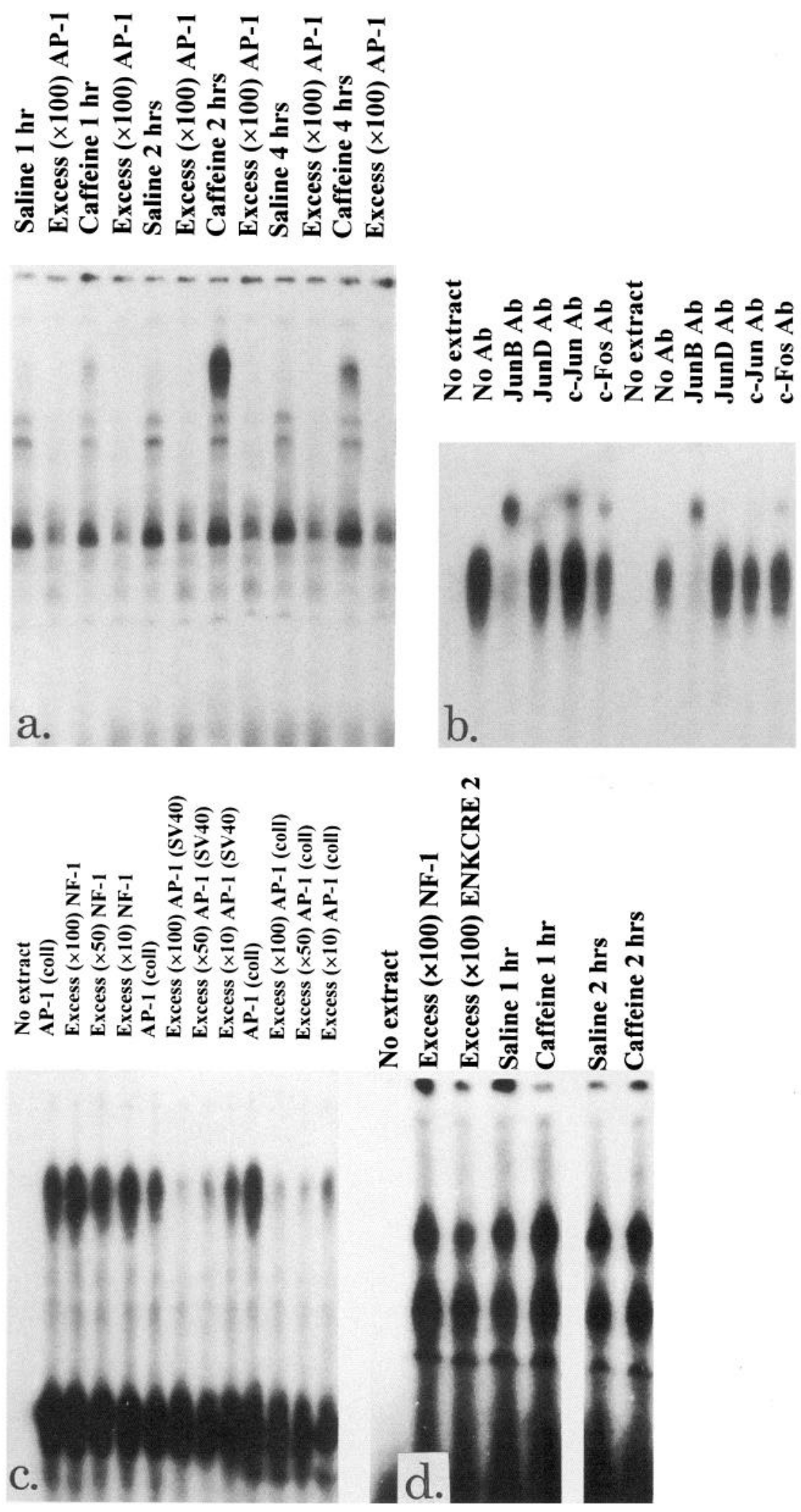

Figure 8. $a$, Gel-shift assay showing the expression of AP-1 in striatum of rats treated with saline or caffeine (100 $\mathrm{mg} / \mathrm{kg}$ ). The AP-1 binding site was deduced from the collagenase enhancer. To every second lane, a 100 -fold excess of unlabeled AP-1 binding site was added. The lowermost part of the gel shows free probe. $b$, Gel-shift assay showing the expression of AP-1 in striatum of rats treated with caffeine $(100 \mathrm{mg} / \mathrm{kg})$ and sacrificed after 2 (lanes 1-6) or 4 (lanes 7-12) hr. Antibodies against JunB, JunD, c-Jun, or c-Fos proteins were added to the indicated lanes. c, Control experiment showing the effect of increasing amounts of unlabeled NF-1 binding sites, unlabeled AP-1 (derived from SV 40 promotor or from the collagenase promotor) on the binding of labeled AP-1 from collagenase. $d$, Gel-shift assay showing the binding to ENKCRE-2 of extracts prepared from striatum of rats treated with saline or caffeine $(100$ $\mathrm{mg} / \mathrm{kg}$ ). The extracts from caffeinetreated rats were known to include AP1 ; this was shown by a parallel experiment where we used AP-1 site from the collagenase enhancer. Competition with unlabeled NF-1 and ENKCRE-2 were made with extracts from rats treated with caffeine for $1 \mathrm{hr}$.

phetamine and cocaine (Daly, 1993) it may be of interest to compare their actions on immediate early gene expression. There are some similarities, for example, in that c-fos is induced in the caudate-putamen (Nakajima et al., 1989), but also important differences. For example, we show, using two different oligonucleotide probes, that caffeine is a potent inducer of c-jun, where- as neither amphetamine nor cocaine induces c-jun (Moratalla et al., 1990, 1993). This qualitative difference between cocaine and caffeine may be related to the quantitative difference between the ability of the substances to induce c-fos. It is known that cocaine induces c-fos almost exclusively in dopamine $\mathrm{D}_{\text {, recep- }}$ tor and substance $\mathrm{P}$-expressing medium-sized spiny neurons 


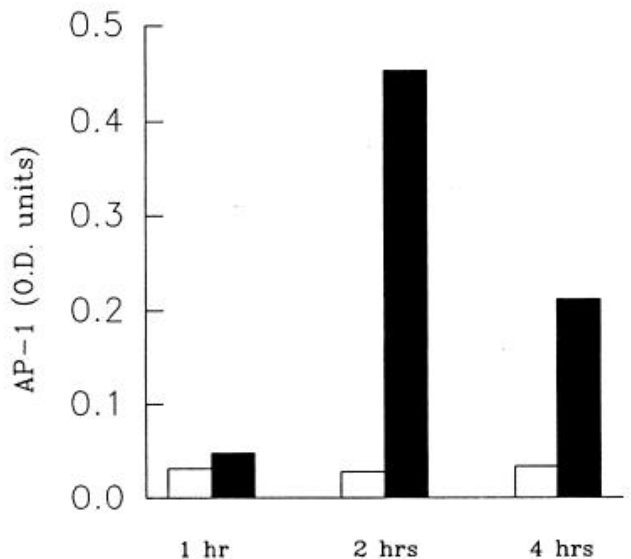

Figure 9. Histogram showing the time course of AP-1 expression in striatum following saline $(\square)$ or caffeine $(\square)$ treatment $(100 \mathrm{mg} / \mathrm{kg})$. The AP- 1 expression was quantitated using image analysis. The findings were replicated twice using the same probe (derived from SV 40 promotor) and twice with a different probe (derived from the collagenase promotor) with qualitatively identical results.

(Graybiel et al., 1990; Young et al., 1991; Beretta et al., 1992; Cole et al., 1992), whereas caffeine induces c-fos also in neurons that express met-enkephalin (Johansson et al., 1994). Approximately half of the medium-sized spiny neurons in striatum belong to the class that express large amounts of dopamine $\mathrm{D}_{1}$ receptor mRNA, whereas the other half of the cells predominantly express dopamine $\mathrm{D}_{2}$ receptor and preproenkephalin mRNA (Gerfen et al., 1990). The present results show that both $\mathrm{c}$-fos and jun $\mathrm{B}$ increase in considerably more than half the cells of the caudate-putamen, and not only in the subpopulation of cells expressing abundant dopamine $\mathrm{D}_{1}$ receptor mRNA but also in the other, equally large, subpopulation of cells. c-jun was also induced in both the subpopulations of cells, albeit to a much more limited extent.

The finding that the examined immediate early genes show somewhat different spatiotemporal characteristics might also be related to in vitro studies that have shown that fos and jun oncogenes are differently regulated (e.g., Bartel et al., 1989; Gubits et al., 1990; Worley et al., 1990). For example, the 5'-flanking sequences of c-fos and jun $\mathrm{B}$ genes possess elements responsive to $\mathrm{cAMP}$ and protein kinase A, whereas that of c-jun lacks these elements (Angel et al., 1988; Lamph et al., 1988; Sassone-Corsi et al., 1988; Chiu et al., 1989; de Groot et al., 1991). It has been proposed that the coordinate expression of c-fos and jun B following cocaine administration could be the result of an activation of a calcium- and cAMP response element secondary to the activation of dopamine $D_{1}$ receptors (Graybiel et al., 1990; Moratalla et al., 1993). The lack of effect of cocaine on c-jun expression was suggested perhaps to be due to active repression by cAMP or by junB (Moratalla et al., 1993). Since caffeine could induce c-jun, c-fos, and jun $\mathrm{B}$ in the same types of cells, it could perhaps be concluded that the caffeine effect is unrelated to cAMP. Indeed, despite the fact that caffeine is inter alia an inhibitor of cAMP breakdown, its effects on c-fos induction cannot be mimicked by selective phosphodiesterase inhibitors (Svenningsson, Johansson, and Fredholm, unpublished observations).
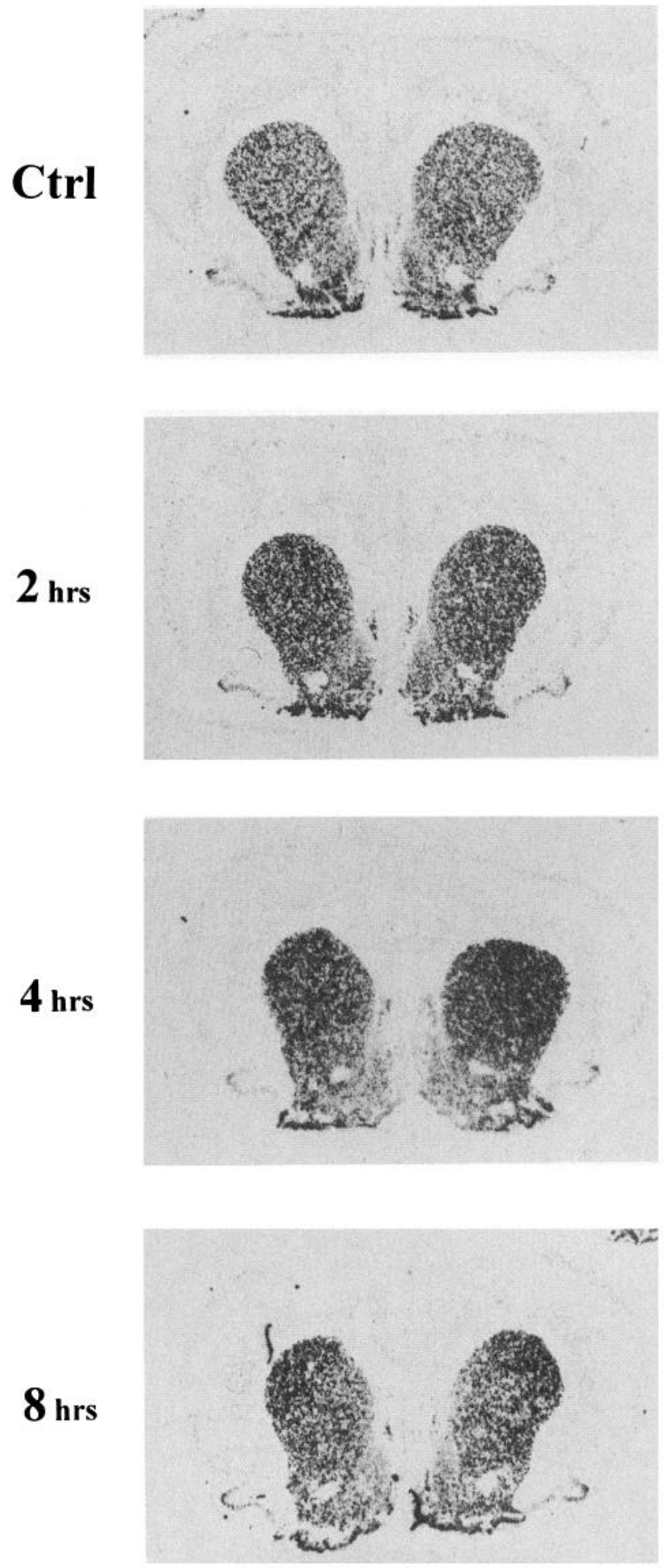

Figure 10. In situ hybridization autoradiograms showing the distribution of preproenkephalin mRNA expression in coronal sections through the rostral part of striatum of rats treated with saline and sacrificed after $2 \mathrm{hr}(\mathrm{Ctrl})$ or treated with caffeine $(100 \mathrm{mg} / \mathrm{kg})$ and sacrificed after 2,4 , or $8 \mathrm{hr}$.

\section{Effects of caffeine on immediate early genes in brain areas related to caudate-putamen}

Nucleus accumbens receives an important dopaminergic innervation from the ventral tegmental area, which is proposed to 

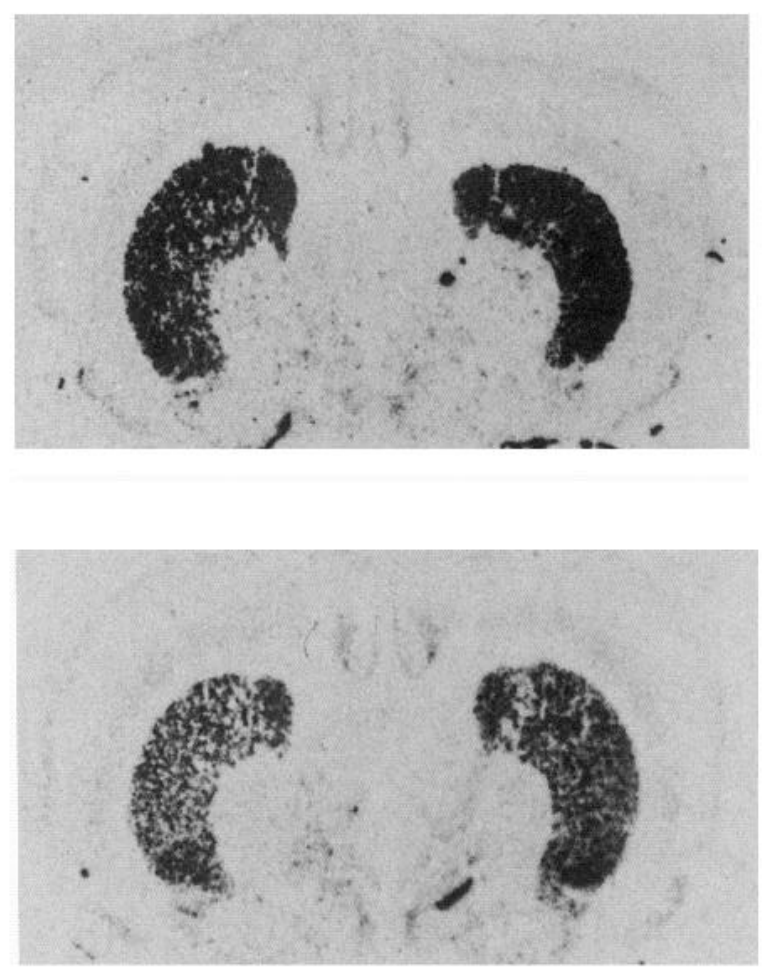

Figure 11. In situ hybridization autoradiograms showing the distribution of preproenkephalin mRNA expression from coronal sections through the caudal part of striatum of rats treated with caffeine (100 $\mathrm{mg} / \mathrm{kg}$ ) (upper panel) or saline (lower panel) and sacrificed after $4 \mathrm{hr}$.

play key role in the development of drug abuse (Koob, 1992). We previously found that caffeine, in contrast to cocaine and amphetamine, gives little or no induction of c-fos in this nucleus (Johansson et al., 1994). Acute cocaine was found to cause a marked increase in i.a. junB and c-jun in nucleus accumbens as judged by Northern blotting (Hope et al., 1992), whereas the induction as judged by in situ hybridization was modest in magnitude or absent (Moratalla et al., 1993). The present finding that administration of caffeine $(100 \mathrm{mg} / \mathrm{kg})$ caused a clearcut increase of jun $\mathrm{B}$ in at least part of nucleus accumbens indicates that this region is affected by caffeine. Actions in the nucleus accumbens may be of significance since caffeine has been described as a weak reinforcing drug (Griffiths and Woodson, 1988; Holtzman and Finn, 1988).

A possible explanation for the ability of caffeine to produce a quantitatively and qualitatively different increase in immediate early genes than does cocaine might be that cocaine acts directly in striatum, whereas caffeine activates it largely indirectly. Unpublished data indicate that the induction of c-fos is altered when rats are pretreated with glutamate receptor antagonists (Svenningsson, Johansson, and Fredholm, unpublished data). One probable explanation is that a component of the effects of caffeine is due to actions on glutamatergic afferent pathways from striatum. In this study we report an increase of c-jun in the ventral part of thalamus and of jun B in cerebral cortex by caffeine; both these areas interact intimately with striatum (for reviews, see Albin et al., 1989; Gerfen et al., 1992). The ventral part of thalamus provides an important striatal output and provides input to cerebral cortex. The mechanism is probably related to the inhibition, by caffeine, of adenosine $A_{1}$ receptors
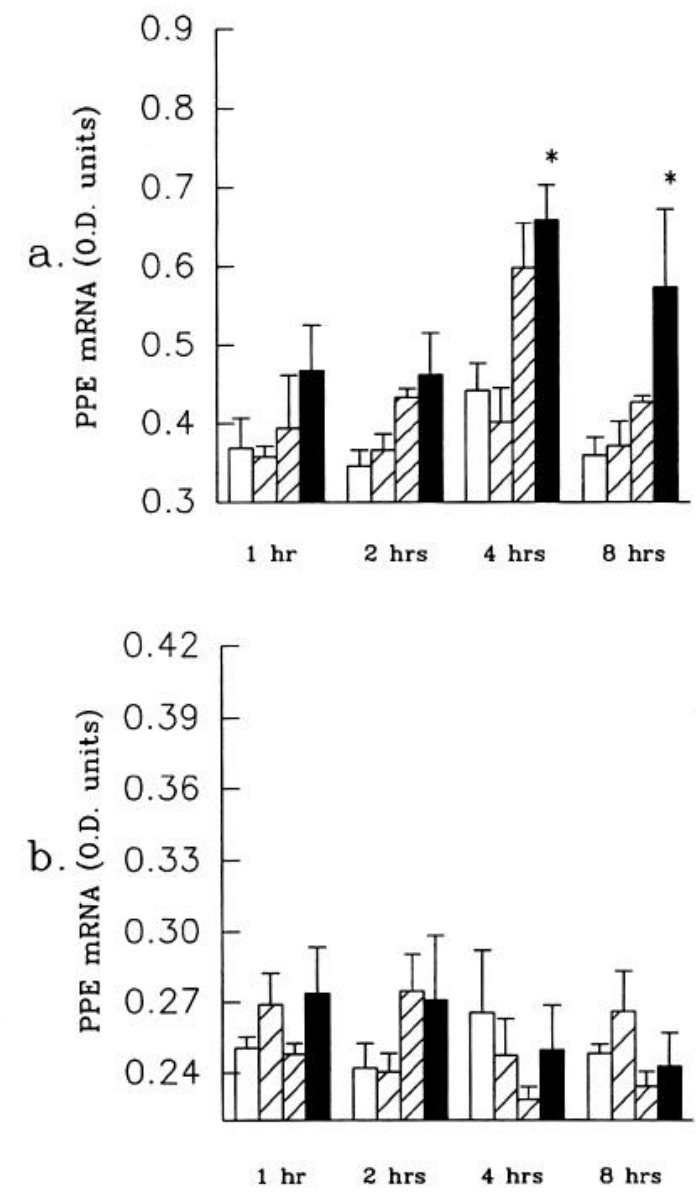

Figure 12. Histograms showing preproenkephalin (PPE) mRNA expression in the lateral part of rostral caudate-putamen $(a)$ and the nucleus accumbens $(b)$ following treatment with saline $(\square)$, caffeine 25 $\mathrm{mg} / \mathrm{kg}(\square)$, caffeine $50 \mathrm{mg} / \mathrm{kg}(\square)$, or caffeine $100 \mathrm{mg} / \mathrm{kg}(\square)$. The results are given as the mean \pm SEM from three individuals in each group. ${ }^{*}, P<0.05$, each versus corresponding saline treated.

that decrease the release of glutamate (Fredholm and Dunwiddie, 1988).

Caffeine induces $c$-Fos-, $c$-Jun-, and JunB-containing AP-I and preproenkephalin $m R N A$

The products of the immediate early genes of the fos/jun family are known to associate in a variety of dimers that bind to the AP-1 site known to regulate the expression of many genes. Specifically, it has been shown that induction of c-fos, c-jun, jun B mRNA precedes induction of proenkephalin mRNA in hippocampus (Sonnenberg et al., 1989a). These authors also showed that synthetic c-Fos/c-Jun and c-Fos/JunB complexes bind to the AP-1-like site called ENKCRE-2 in the 5'-flanking sequence of the preproenkephalin gene. In another paper from the same group (Sonnenberg et al., 1989b) it was shown that AP-1 binding activity was induced, and it was suggested that the composition of the transcription factor may vary with time. Given this background, which was available to us at the start of our study, the data presented in the present study imply that c-fos, c-jun, and jun $\mathrm{B}$, via formation of AP-1, contribute to the regulation of enkephalin expression in the caudate putamen following caffeine exposure. Thus, AP-1 binding activity was detected somewhat after the first induction of the immediate early gene mRNA. It was also shown, by super-shift assay, that at least part of the 
AP-1 binding activity was composed of JunB, c-Fos, and c-Jun. Finally, and with a still greater time lag, there was an increased expression of preproenkephalin mRNA. However, in a careful study, Fos-containing AP-1 was found to play little or no role in the induction of proenkephalin by haloperidol treatment (Konradi et al., 1993). Instead, the study provided evidence that CREB binds and regulates via phosphorylation of the ENKCRE-2 sitc. We similarly found that caffeine did not alter binding to ENKCRE-2, using the same sequence as that used by Konradi et al. (1993). Therefore the causal link between the induction of AP- 1 and the induction of preproenkephalin mRNA is highly uncertain. In the case of two other neuropeptides, neurotensin and substance $\mathrm{P}$, the role of Fos and AP-1 may be bigger (Merchant and Miller, 1994). These two peptides are also affected by caffeine (Schiffmann and Vanderhategen 1993b; P. Svenningsson, U. Ådén, and B. B. Fredholm, unpublished data). Interestingly, in the 5 -flanking sequence of substance $P$, one detects an AP-1 binding site identical to the AP-1 site in the collegenase enhancer, which we used in this experiment (Carter and Krause, 1990).

The present data thus show that a single dose of caffeine can induce marked changes not only in immediate early gene expression but also in the expression of genes that respond to the transcription factors that these genes elaborate. It is tempting to speculate that such changes may underlie the well-known adaptive changes that occur in brain following caffeine treatment. For example, in naive subjects a dose of caffeine activates the sympathoadrenal system resulting, for example, in increases in blood pressure. However, subsequent doses produce progressively smaller effects and within a few days no effect is observed (Robertson et al., 1981). Furthermore, there is evidence for behavioral tolerance (see Holtzman and Finn, 1988) and a few days of caffeine treatment in rodents significantly alters their susceptibility to drug-induced seizures (Georgiev et al., 1993) and to damage following global or regional ischemia (Rudolphi et al., 1989).

\section{References}

Albin RL, Young AB, Penney JB (1989) The functional anatomy of basal ganglia disorders. Trends Neurosei 12:366-375.

Angel P, Hattori K, Smeal T, Karin M (1988) The jun proto-oncogene is positively autoregulated by its product, Jun/AP-1. Cell 55:875-885.

Angulo JA (1992) Involvement of dopaminc $D_{1}$ and $D_{2}$ receptors in the regulation of pro enkephalin mRNA abundance in the striatum and accumbens of the rat brain. J Neurochem 58:1104-1109.

Bartel DP, Sheng M, Lau LF, Greenberg ME (1989) Growth factors and membrane depolarization activate distinct programs of early response gene expression: dissociation of fos and jun induction. Genes Dev 3:304-313.

Berretta S, Robertson HA, Graybiel AM (1992) Dopamine and glutamate agonists stimulate neuron-specific expression of Fos-like protein in the striatum. J Neurophysiol 68:767-777.

Bradford MM (1976) A rapid and sensitive method for the quantitation of microgram quantities of protein utilizing the principle of proteindye binding. Anal Biochem 72:248-254.

Carter MS, Krause JE (1990) Structure, expression, and some regulatory mechanisms of the rat preprotachykinin genc cncoding substance P, neurokinin A, neuropeptide K and neuropeptide $\gamma$. J Neurosci 10: 2203-2214.

Chiu R, Angel P, Karin M (1989) Jun-B differs in its biological properties from, and is a negative regulator of, c-jun. Cell 59:979-986.

Chodosh LA, Baldwin AS, Carthew RW, Sharp PA (1988) Human CCAAT-binding proteins have heterologous subunits. Cell 53:11-24.

Cole AJ, Bhat RV, Patt C, Worley PF, Baraban JM (1992) D, dopamine receptor activation of multiple transcription factor genes in the rat striatum. J Neurochem 58:1420-1426.

Comb M, Mermod N, Hyman SE, Pearlberg J, Ross ME, Goodman HM
(1988) Proteins bound at adjacent DNA elements act synergistically to regulate human proenkephalin cAMP inducible transcription. EMBO J 7:3793-3805.

Curran T, Gordon MB, Rubino KL, Sambucetti LC (1987) Isolation and characterization of the c-fos (rat) cDNA and analysis of posttranscriptional modification in vitro. Oncogene 2:79-84.

Curran T, Abate C, Cohen DR, Macgrcgor PF, Rauscher FJ III, Sonnenberg JL, Connor JA, Morgan JI (1990) Inducible proto-oncogene transcription factors: third messengers in the brain? Cold Spring Harbor Symp Quant Biol 55:225-234.

Daly JW (1993) Mechanism of action of caffeine. In: Caffeine, coffee and health (Garattini S, ed), pp 97-150. New York: Raven.

deCeballos ML, Boyce S, Jenner P, Marsden CD (1986) Alterations in [met ${ }^{5}$ - and [leu $\left.{ }^{5}\right]$-enkephalin and neurotensin content in the basal ganglia induced by the long-term administration of dopamine agonist and antagonist drugs to rats. Eur J Pharmacol 130:305-309.

de Groot RP, Auwerx J, Karperien M, Staels B, Kruijer W (1991) Activation of junB24 by PKC and PK $\Lambda$ signal transduction through a novel cis-acting element. Nucleic Acids Res 19:775-781.

Dragunow M, Robertson HA (1987) Kindling stimulation induces c-fos protein(s) in granule cells of the rat dentate gyrus. Nature 329:441442.

Fastbom J, Pazos A, Palacios JM (1987) The distribution of adenosine $A_{1}$ receptors and 5 -nucleotidase in the brain of some commonly used experimental animals. Neuroscience 22:813-826.

Fredholm BB (1980) Are methylxanthine effects due to antagonism of endogenous adenosine? Trends Pharmacol Sci 1:129-132.

Fredholm BB, Dunwiddie TV (1988) How does adenosine inhibit transmitter release? Trends Pharmacol Sci 9:130-134.

Fredholm BB, Abbracchio MP, Burnstock G, Daly JW, Harden TK, Jacobson KA, Leff P, Williams M (1994) Nomenclature and classification of purinoceptors: a report from the IUPHAR subcommittee. Pharmacol Rev 46:143-156.

Georgiev V, Johansson B, Fredholm BB (1993) Long-term caffeine treatment leads to a decreased suspectibility to NMDA-induced clonic seizures in mice without changes in adenosine $A_{1}$ receptor number. Brain Res 612:271-277.

Gerfen GR (1992) The neostriatal mosaic: multiple levels of compartmental organization. Trends Neurosci 15:133-139.

Gerfen CR, Young WS III (1988) Distribution of striatonigral and striatopallidal peptidergic neurons in both patch and matrix compartments: an in situ hybridization histochemistry and fluorescent retrogradc tracing study. Brain Res 460:161-167.

Gerfen CR, Engber TM, Mahan LC, Susel Z, Chase TN, Monsma FJ Jr, Sibley DR (1990) D1 and D2 dopamine receptor-regulated gene expression of striatonigral and striatopallidal neurons. Science 250: $1429-1432$.

Gerfen CR, McGinty JF, Young WS III (1991) Dopamine differentially regulates dynorphin, substance $P$, and enkephalin expression in striatal neurons: in situ hybridization histochemical analysis. J Neurosci 11:1016-1031.

Graybiel AM, Moratalla R, Robertson HA (1990) Amphetamine and cocaine induce drug-specific activation of the c-fos gene in striosomematrix compartments and limbic subdivisions of the striatum. Proc Natl Acad Sci USA 87:6912-6916.

Griffiths RR, Woodson PP (1988) Reinforcing properties of caffeine: studies in humans and laboratory animals. Pharmacol Biochem Behav 29:419-427.

Gubits RM, Wollack JB, Yu H, Liu W-K (1990) Activation of adenosine receptors induces c-fos, but not $\mathrm{c}$-jun, expression in neuronglia hybrids and fibroblasts. Mol Brain Res 8:275-281.

Herdegen T, Tölle TR, Bravo R, Zieglgänsberger W, Zimmermann M (1991a) Sequential expression of JunB, JunD and FosB proteins in rat spinal neurons: cascade of transcriptional operations during nociception. Neurosci Lett 129:221-224.

Herdegen T, Leah JD, Manisali A, Bravo R, Zimmermann M (1991b) c-Jun-like immunoreactivity in the CNS of the adult rat: basal and transynaptically induced expression of an immediately-early gene. Neuroscience 41:643-654.

Hirai S-I, Ryseck RP, Mechta F, Bravo R, Yaniv M (1989) Characterization of jun D: a new member of the jun proto-oncogene family. EMBO J 8:1433-1439.

Holtzman SG, Finn IB (1988) Tolerance to behavioral effects of caffeine in rats. Pharmacol Biochem Behav 29:411-418.

Hope B, Kosofsky B, Hyman SE, Nestler EJ (1992) Regulation of 
immediate early gene expression and AP-1 binding in the rat nucleus accumbens by chronic cocaine. Proc Natl Acad Sci USA 89:57645768.

Johansson B, Lindström K, Fredholm BB (1994) Differences in the regional and cellular localization of c-fos mRNA induced by amphetamine, cocaine and caffeine. Neuroscience 59:837-849.

Jones NC, Rigby PWJ, Ziff EB (1988) Trans-acting protein factors and the regulation of eukaryotic transcription: lessons from studies on DNA tumor viruses. Genes Dev 2:267-281.

Konradi C, Kobierski LA, Nguyen TV, Heckers S, Hyman SE (1993) The cAMP-response-element-binding protein interacts, but Fos protein does not interact, with the preproenkephalin enhancer in rat striatum. Proc Natl Acad Sci USA 90:7005-7009.

Koob GF (1992) Drugs of abuse: anatomy, pharmacology and function of reward pathways. Trends Pharmacol Sci 13:177-184.

Krause JE, Chirgwin JM, Carter MS, Xu S, Hershey AD (1987) Three rat preprotachykinin mRNAs encode the neuropeptides substance $\mathrm{P}$ and neurokinin A. Proc Natl Acad Sci USA 84:881-885.

Lamph WW, Wamsley P, Sassone-Corsi P, Verma IM (1988) Induction of proto-oncogene jun/AP-1 by serum and TPA. Nature 334:629-631.

Lee W, Mitchell P, Tjian R (1987) Purified transcription factor AP-1 interacts with TPA-inducible enhancer elements. Cell 49:741-752.

Mellström B, Achaval M, Montore D, Naranjo IR, Sassone-Corsi P (1991) Differential expression of the jun family members in rat brain. Oncogene 6:1959-1964.

Merchant KM, Miller MA (1994) Coexpression of neurotensin and c-fos mRNAs in rat neostriatal neurons following acute haloperidol. Mol Brain Res 23:271-277.

Moratalla R. Robertson HA, DiZio PA, Graybiel A (1990) Parallel induction of $j u n \mathrm{~B}$ and $\mathrm{c}-f o s$ evoked in the striatum by the psychomotor stimulant drugs cocaine and amphetamine. Soc Neurosci Abstr 16:953.

Moratalla R, Robertson HA, Graybiel AM (1992) Dynamic regulation of NGFI-A (zif268, egrl) gene expression in the striatum. J Neurosci 12:2609-2622.

Moratalla R, Vickers EA, Robertson HA, Cochran BH, Graybiel AM (1993) Coordinate expression of $\mathrm{c}-$ fos and $j u n \mathrm{~B}$ is induced in the rat striatum by cocaine. J Neurosci 13:423-433.

Morgan JI, Cohen DR, Hempstead JL, Curran T (1987) Mapping patterns of c-fos expression in the central nervous system after seizure. Science 237:192-197.

Nakabeppu Y, Ryder K, Nathans D (1988) DNA binding activities of three murine jun proteins: stimulation of Fos. Cell 55:907-915.

Nakajima T, Daval J, Morgan PF, Post RM, Marangos PJ (1989) Adenosinergic modulation of caffeine-induced c-fos mRNA expression in mouse brain. Brain Res 501:307-314.

Nehlig A, Daval J-L, Debry G (1992) Caffeine and the central nervous system: mechanisms of action, biochemical, metabolic and psychostimulant effects. Brain Res Rev 17:139-170.

Nestler EJ, Hope BT, Widnell KL (1993) Drug addiction: a model for the molecular basis of neural plasticity. Neuron 11:995-1006.

Nguyen TV, Kosofsky BE, Birnbaum R, Cohen BM, Hyman SE (1992) Differential expression of $\mathrm{c}$-Fos and $Z$ if 268 in rat striatum after haloperidol, clozapine, and amphetamine. Proc Natl Acad Sci USA $89: 4270-4274$

Parkinson FE, Fredholm BB (1990) Autoradiographic evidence for G-protein coupled $\mathrm{A}_{2}$-receptors in rat neostriatum using $\left[{ }^{3} \mathrm{H}\right]$-CGS 21680 as a ligand. Naunyn-Schmiedeberg's Arch Pharmacol 342:8589.

Robertson D, Wade D, Workman R, Woosley RL, Oates JA (1981) Tolerance to the humoral and hemodynamic effects of caffeine in man. J Clin Invest 67:1111-1117.

Rudolphi KA, Keil M, Fastbom J, Fredholm BB (1989) Ischaemic damage in gerbil hippocampus is reduced following upregulation of adenosine $\left(A_{1}\right)$ receptor by caffeine treatment. Neurosci Lett 103: 275-280.

Ryder K, Lau LF, Nathans D (1988) A gene activated by growth factors is related to the oncogene v-jun. Proc Natl Acad Sci USA 85:14871491.

Saflen DW, Cole AJ, Worley PF, Christy BA, Ryder K, Baraban JM (1988) Convulsant-induced increase in transcription factor messenger RNAs in rat brain. Proc Natl Acad Sci USA 85:7795-7799.

Sagar SM, Sharp FR, Curran T (1988) Expression of c-fos protein in brain: metabolic mapping at the cellular level. Science 240:13281331.

Sassone-Corsi P, Lamph WW, Verma IM (1988) Regulation of protooncogene fos: a paradigm for early response genes. Cold Spring Harhor Symp Quant Biol 53:749-760.

Schiffmann SN, Vanderhaeghen J-J (1993a) Adenosine $A_{2}$ receptors regulate the gene expression of striatopallidal and striatonigral neurons. $J$ Neurosci 3:1080-1087.

Schiffmann SN, Vanderhaeghen J-J (1993b) Caffeine regulates neurotensin and cholecystokinin messenger RNA expression in the rat strialun. Neuroscience 54:681-689.

Schiffmann SN, Jacobs OP, Vanderhaeghen J-J (1991) Striatal restricted adenosine $\mathrm{A}_{2}$ receptor (RDC8) is expressed by enkephalin but not by substance P neurons: an in situ hybridization histochemistry study. J Neurochem 57:1062-1067.

Sonnenberg JL, Rauscher FJ III, Morgan JI, Curran T (1989a) Regulation of proenkephalin by Fos and Jun. Science 246:1622-1625.

Sonnenberg JL, Macgregor-Leon PF, Curran T, Morgan JI (1989b) Dynamic alterations occur in the levels and composition of transcription factor AP-1 complexes after seizure. Neuron 3:359-365.

Tang F, Costa E, Schwartz J (1983) Increase of proenkephalin mRNA and enkephalin content of rat striatum after daily injection of haloperidol for 2 to 3 weeks. Proc Natl Acad Sci USA 80:3841-3844.

Taylor MD, DeCeballos ML, Jenner P, Marsden CD (1991) Acute effects of $\mathrm{d}-1$ and $\mathrm{d}-2$ dopamine receptor agonist and antagonist drugs on basal ganglia $\left[\mathrm{met}^{5}\right]$ - and [leu $\left.{ }^{5}\right]-e n k e p h a l i n$ and neurotensin content in the rat. Biochem Pharmacol 41:1385-1391.

Thierry F, Spyrou G, Yaniv M, Howley P (1992) Two AP-1 sites binding JunB are essential for human papillomavirus type 18 transcription in keratinocytes. J Virol 66:3740-3748.

Uhl GR, Walther D, Nishimoti T, Buzzi MG, Moskowitz MA (1991) junB, c-jun, junD and c-fos mRNAs in nucleus caudalis neurons: rapid selective enhancement by afferent stimulation. Mol Brain Res 11:133-141.

Wang X-B, Watanabe Y, Osugi T, Ikemoto M, Hirata M, Miki N (1992) In situ DN $\Lambda$-protein binding: a novel method for detecting DNAbinding activity of transcription factor in brain. Neurosci Lett 146: 25-28.

Wisclen W, Errington ML, Williams S, Dunnett SB, Waters C, Hitchcock D, Evan G, Bliss TVP, Hunt SP (1990) Differential expression of immediately early genes in the hippocampus and spinal cord. Neuron 4:603-614.

Worley PF, Cole AJ, Murphy TH, Christy BA, Nakabeppu Y, Baraban JM (1990) Synaptic regulation of immediate-early genes in brain. Cold Spring Harbor Symp Quant Biol 55:213-223.

Yoshikawa K, Williams C, Sabol SL (1984) Rat brain preproenkephalin mRNA. J Biol Chem 259:14301-14308.

Young ST, Porrino LJ, Iadanola MJ (1991) Cocaine induces striatal c-Fos immunoreactive proteins via dopaminergic $D_{1}$ receptors. Proc

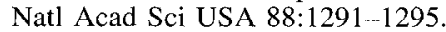

Young WS III, Bonner TI, Brann MR (1986) Mesencephalic dopamine neurons regulate the expression of neuropeptide mRNAs in the rat furebrain. Proc Natl Acad Sci USA 83:9827-9831. 